\title{
A Tale of Two Tables: Echoes of the Past in the Canons of the Sainte-Croix Gospels
}

\begin{abstract}
The Gospels of Sainte-Croix of Poitiers of $c .800$ contains an unusual double set of canon tables. Early initia canons, which provide snippets of text along with each number reference, are followed by another complete set of tables within architectural arcades. Written by the hand of a single scribe, there is no question that these two tables were intentionally included together. Why? This essay argues that these antiquated initia canons, which are paired with early versions of letters by Eusebius and Jerome, provided a sense of tradition and historical foundation for the Carolingian canons, illumination, and gospel text that followed.
\end{abstract}

Carl Nordenfalk imagined the regal arches of canon tables as 'a propylaeum through which we approach the sanctum sanctorum of the Holy Writ'. ${ }^{1}$ This perspective has lingered in scholarship as a compelling way of conceptualizing what often appears to be a dry chart of numbers, for it transforms them instead into a meaningful and symbolic gateway. In a sense, these charts provide a scaffolding for understanding the word of God through an architecture that is both literal as well as theological. By the Carolingian period, canon tables had become a key and expected component of gospel books, whether intended for active use or else as simply part of the visual apparatus. Yet, as all those who study medieval manuscripts know, just when things start to become predictable, we find something unexpected that throws a wrench into our tidy, linear thinking.

It can be said of many things in life that while having one is good, having two is even better... but it is hard to imagine this logic applying to sets of canon tables. However, in one unusual manuscript, its creator decided to double down on them with remarkable gusto, committing a staggering twenty-one folios, or forty-two pages, to two different forms of canon tables. The traditional, expected architectural set is preceded by yet another, one that lacks such visual theatricality, and which provides a wholly different and unconventional approach. As the canons are also accompanied by some unexpected letters and poetry, the overall prefatory material fills nearly four quires. For the reader of this book, the elegant procession

1 Nordenfalk 1982, 30. through marbled arches envisioned by Nordenfalk just turned into an exhausting marathon.

The manuscript in question is the Sainte-Croix Gospels of Poitiers, which will henceforth be referred to as Poitiers $17^{2}$ A highly individualized book, it was likely produced $c .800$ at the Corbie scriptorium in northern France. ${ }^{3}$ It is a large manuscript, consisting of 213 folios and measuring $31.4 \times 22.5 \mathrm{~cm}$ even in its cropped condition, making it similar in size to luxury books such as the Book of Kells $(33 \times 25.5 \mathrm{~cm})$ and the Ada Gospels $(36.5 \times 24$ $\mathrm{cm}) .{ }^{4}$ A wide variety of pigments, including costly gold, silver, and blue, were used in the canon tables, the image, and the incipits of the gospels. There is no question that the manuscript represents a significant investment of time and materials. However, it is full of unusual choices by its creators, resulting in the book being repeatedly dismissed by scholars as bizarre, and labeled a provincial anomaly. ${ }^{5}$ This stigma is largely due to its lone miniature, a unique Maiestas Domini whose complexity has been mistaken for muddiness and lack of artistic aptitude. Yet, in many ways the unconventional textual choices made when designing the book also lend to this aura of idiosyncrasy. Although a few scholars have attempted to make sense of Poitiers 17 over the past few centuries, its quirkiness has made them hesitant to embrace this book within the canon of Carolingian manuscripts. ${ }^{6}$ Part of the confusion may in fact be due to the approach of past scholarship, which has often focused on one specific aspect of the manuscript or another. Taken piecemeal, it is easy to see how the various components of the book might feel incoherent and even discordant. It is only when the book is considered as a unified whole, and assumed to have an underlying inten-

2 Poitiers, Médiathèque François Mitterrand, MS 17 (65), Réserve précieuse. The manuscript has been catalogued and fully digitized, and is available here: http://www.bm-poitiers.fr/PATRIMOINENUM/ doc/SYRACUSE/1029419/livre-d-evangiles-de-l-abbaye-sainte-croix (last accessed 13/04/2020). This manuscript was the focus of my dissertation, which is currently being developed into a book. For the dissertation, see Herbert 2012. See also Herbert 2016, 143-168.

3 For arguments that it was produced in Corbie, see Palazzo 2006, 67-81, and Herbert 2012, 86-99.

4 Dublin, Trinity College, MS 58 (A.I.6), and Trier, Stadtbibliothek, MS 22. 5 For a historiography of the manuscript, and discussion of the language used to describe it, see Herbert 2012, 1-10.

6 This fact is slowly being rectified, and Nees 2020 (forthcoming) places it in context with contemporary Frankish manuscripts. 
tionality, that a larger programme reveals itself. This essay argues that the reader is intended to discover a progression throughout this manuscript, with its various components building chronologically, textually, and visually toward a climax provided by the image, and the gospels themselves.

The unusual composition of the prefatory materials, especially in terms of having a second set of canon tables, raises some natural and legitimate questions. Were they even original to the book? Could they have been from something else, and were perhaps added to this manuscript later? It is easy to assume that there must be something codicologically amiss-something that would indeed point to two projects having been cobbled together as often happened over time in early manuscripts. However, this is not the case. These texts have been carefully and thoughtfully crafted, and this same level of care and precision in design is evident in all facets of the book's production. The manuscript was composed of perfect quires of eight from beginning to end, and the texts flow from one quire to the next, so there is no question that it was planned out as it exists now. ${ }^{7}$ It is also almost entirely the work of a single scribe, ${ }^{8}$ who painstakingly copied out the text in a formal and elegant uncial script. There are three other known manuscripts by the same scribe, and from these it is clear that he was adept at writing in the new and more modern Caroline minuscule, so his use of full uncial here is a choice. ${ }^{9}$ This script, found in the earliest gospel books, lends this book an air of great antiquity, a visual cue to the reader that evokes centuries of tradition, and provides continuity with the past.

The opening texts of the Poitiers manuscript reinforce that aura of antiquity that is visually conveyed through the script. The first of these texts is an undecorated copy of Eusebius's Letter to Carpianus (fols 2r-v, Fig. 1). ${ }^{10}$ This

7 The collation is as follows: Quire 1: 8, lacking original first 2 folios, with second replaced (fols 1-7); Quires 2-26: 8 (fols 8-206); Quire 27: 8, lacking last folio (fols 207-214).

8 Two scribes are evident: one main scribe was responsible for the majority of the manuscript, while one secondary scribe with a shaky hand copied occasional bifolia (e.g. fols $177 \mathrm{v}-178 \mathrm{r}$ and $181 \mathrm{v}-182 \mathrm{r}$ ).

9 The other three manuscripts that have been identified as being by this scribe are Bamberg, Staatsbibliothek, Patr. 86 (B.V.13), Cambridge, Magdalene College, Pepysian 2981 (I), and Leiden, Bibliotheek der Rijksuniversiteit, Voss. Lat. F. 26. For the discussion of their grouping through a common scribe, see Lowe 1953, cat. no. 821, and Bischoff 1994, 26.

10 The manuscript lacks its original first two folios, with the text beginning discretely on what would have been the third leaf in the original quire structure. It is possible there was something else preceding this text, as the original first two folios of the book are now lost. However, the manuscript originally ended with two blank folios letter was often included in early gospel books as it carries his explanation of how the canon tables he designed work. ${ }^{11}$ However, the appearance of the Eusebius letter in Poitiers 17 is unusual for a number of reasons. For one, by the time this manuscript was produced, Jerome's Novum Opus letter ${ }^{12}$ had become the more standard gospel preface in the western world, and due to its similar and updated content, often superseded Eusebius; where Eusebius's letter does appear, it usually follows Jerome. ${ }^{13}$ In the Poitiers manuscript, Eusebius is given pride of place, and Jerome's letter does not appear until folio $15 \mathrm{v}$. For a western gospel book of $c .800$, this reversal of prominence is highly unusual. Yet it is not only its placement that is remarkable. Pierre Minard pointed out that the version of the Eusebius letter that appears in Poitiers 17 must have been copied from an extremely early and rare version of the text, one that was distinctive for its close adherence to the original Greek. ${ }^{14}$ Indeed, Donatien de Bruyne discovered that the version in Poitiers 17 is virtually identical to that quoted by Victor of Capua in his preface to the Codex Fuldensis, created $c .547$ in northern Italy. ${ }^{15}$ The Codex Fuldensis is the oldest extant version of a gospel harmony like that believed to have been found in the Diatessaron, an early attempt to combine the gospels into a coherent narrative. ${ }^{16}$ The similarities between the Eusebius text in Poitiers 17, and the Codex Fuldensis's, led de Bruyne to believe that the version copied in the former had originally accompanied an early Diatessaron. ${ }^{17}$ Therefore not only is the very presence of the Eusebius letter in Poitiers 17 unusual, both in being included at all in a western manuscript, and in its occupying such a place of honor as the first text, but they also chose an old, outdated version at that. It seems

(only one is still extant), and judging from the meticulous layout of the folios from beginning to end, and the fact that the Eusebius text opens cleanly on its own page, I believe it is likely the first two folios may have been planned as blank flyleaves as well. As there is no way to know for certain whether or not those folios contained text, I must work on the assumption that the Eusebius letter was indeed the beginning of the manuscript.

11 Nordenfalk 1938, 57-72.

12 For Jerome's preface, see Jerome 1975, 1515-16.

13 McGurk 1961, 64, points out how unusual it is for this to be the opening text. For an excellent discussion of the use of this letter, see Oliver 1959, 138-145, and esp. 140. Since the first two folios of the manuscript no longer survive, it is possible that another text, perhaps Jerome's other letter Plures fuisse, could have been inscribed on those two pages. However, there is no indication that text is missing. 14 Minard 1943, 19.

15 Fulda, Landesbibliothek, Bonifatianus 1; De Bruyne 1927, 5-11. 16 For a recent discussion of this text, see Crawford 2016, 253-277. See also Schmid 2003, 176-199, and esp. 177.

17 De Bruyne 1927, 5-11. 


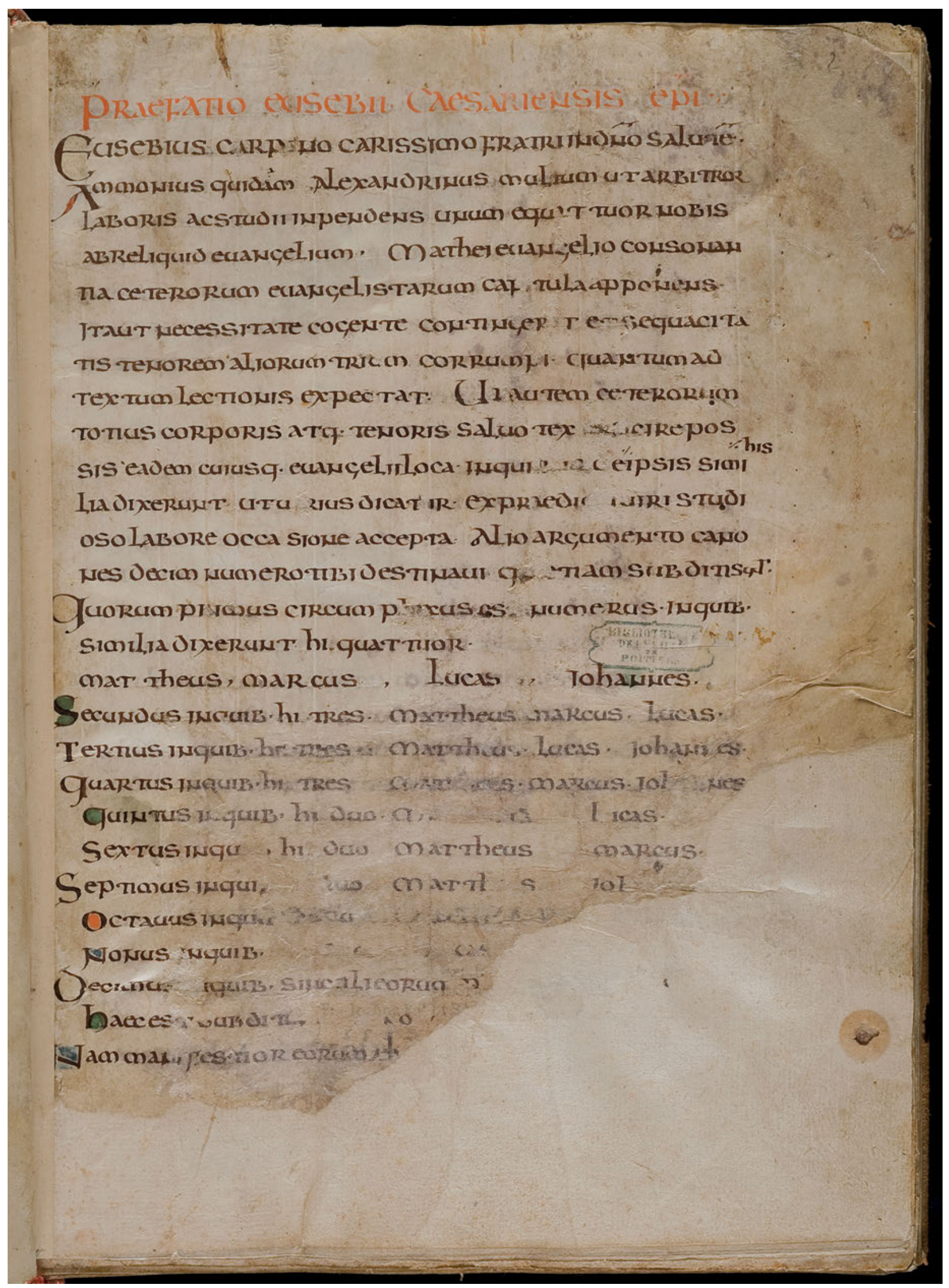

Fig. 1: Eusebius’s letter. Poitiers 17, fol. 2r. @ All images are from Livre d‘Evangiles de l'abbaye Sainte-Croix, Médiathèque FrançoisMitterrand, Poitiers, MS 17 (65). Photogr. by Olivier Neuillé. 


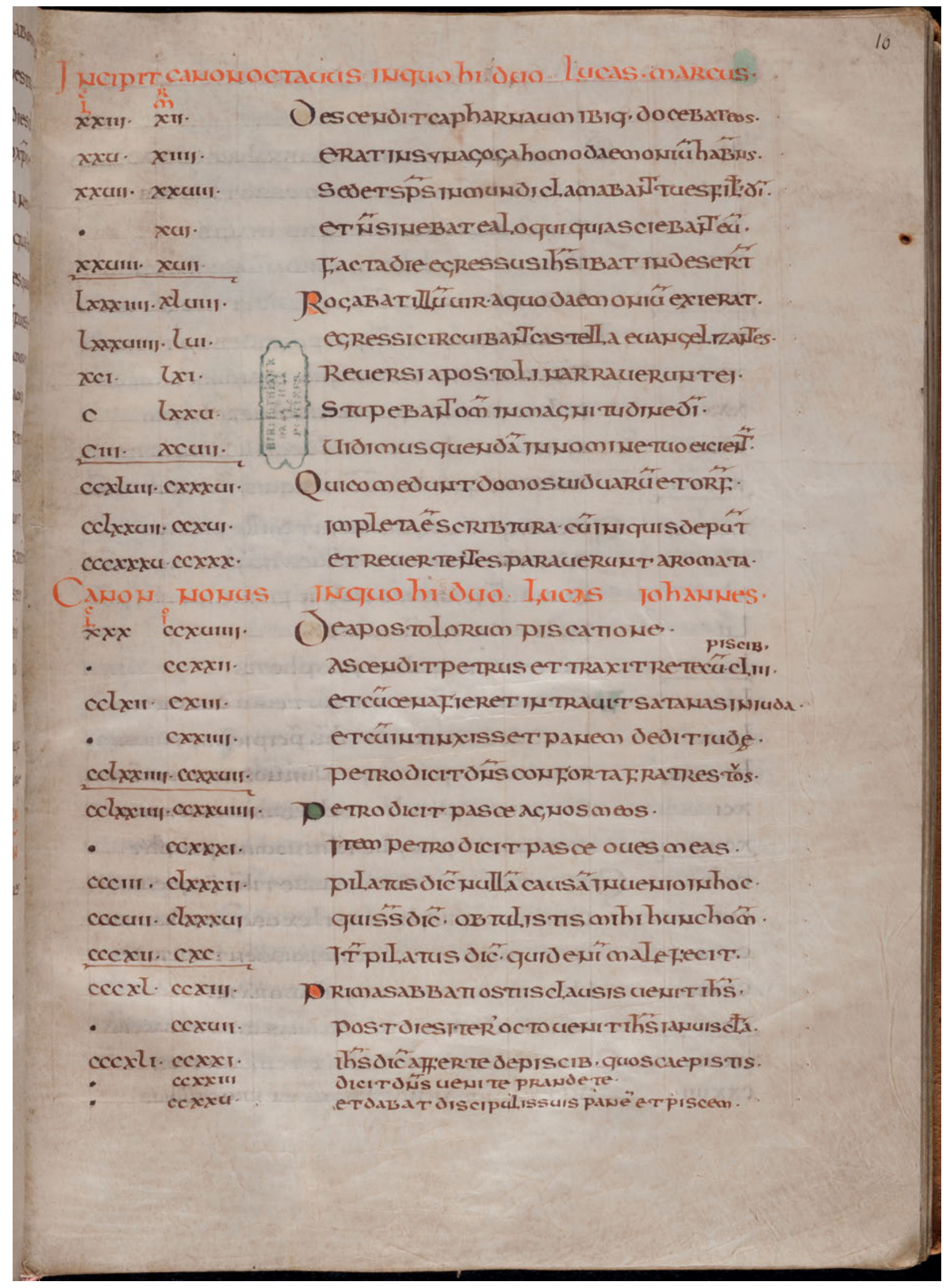

Fig. 2: Initia canons VIII and IX. Poitiers 17, fol. 10r. 
therefore that an intentionally antiquated discussion of the agreement of the gospels was chosen.

The next prefatory element, which is possibly the strangest in the manuscript, picks up on this antiquarianism (Fig. 2). This rare set of initia canon tables is also of an early vintage, and the snippets of text included are based upon an Italian Vetus Latina tradition, being the version that preceded Jerome's Vulgate translation..$^{18}$ The sixth-century Codex Brixianus offers the best comparison, although upon closer textual examination, there are many notable differences in phrasing and word choices between it and the Poitiers initia canons. ${ }^{19}$ There are enough similarities, however, that something like it must have been available to our scribe. Pinning down an exact manuscript in northern France in this period that had this type of initia canons and could have served as an exemplar has not yet proven possible. However, the scriptorium at Corbie, where it is likely the Poitiers manuscript was made, had an extensive library with a large number of early manuscripts from many different origins, as has been well-documented by David Ganz. ${ }^{20}$ One possibility from the Corbie library is the Codex Corbiensis, ${ }^{21}$ which is a fifth-century Italian uncial manuscript of the Vetus Latina version of the gospels. It is now missing its first three quires, and therefore may have originally contained prefatory materials such as those in Poitiers 17. At the very least, it is proof of the availability of the kind of manuscript needed by the scribe.

In these early versions of the canons, the familiar chart of numbers is accompanied by extracts of the gospel passages being indicated. De Bruyne found their presence in Poitiers 17 extremely puzzling, and argued that the Eusebius letter copied along with them may have originally gone with this version of the canons, with both possibly used as prefaces for a Vetus Latina version of the Diatessaron. ${ }^{22}$ The issue of the Diatessaron is far too complicated to explore more fully here, and whether or not that was the source of these texts in Poitiers 17 is debatable. ${ }^{23}$ However, the Eusebius letter and the initia canons certainly seem to

18 Pierre Minard published these canons fully. See Minard 19451946, 58-92. He also listed the other known versions of this type of canon: Vendôme, Bibliothèque municipale, MS 0002; Paris, Bibliotheque Mazarine, MS I; Troyes, Bibliothèque municipale, MS 138; Trèves, Séminaire, MS 40; Brescia, Biblioteca civica Queriniana, s.n. 19 Brixianus: Brescia, Biblioteca civica Queriniana, s.n..

20 Ganz 1990.

21 Paris, Bibliothèque nationale de France, Lat. 17225. For a description of this manuscript, see Ganz 1990, 128.

22 De Bruyne 1927, 10-11.

23 A full discussion of the issues involved can be found in Schmid 2003, 176-199. go well together, both in the way they are paired within the manuscript, and in their shared connections with sixth-century Italian works such as the Codex Fuldensis and the Codex Brixianus. In his letter, Eusebius explains that he took the idea of Ammonius (who was believed to have created a Diatessaron) and tried to find a way to show the agreement between the Evangelists without ruining the coherence of the separate gospels. ${ }^{24}$ The initia canons are essentially a blend of the two approaches-retaining some of the text so it is not just a cryptic list of numbers, yet making it a separate chart that does not affect the gospels themselves, which had made the Diatessaron problematic.

All of this sounds like a logical and useful idea, however in studying the initia canons in Poitiers 17, both the advantages and limitations of this approach start to become apparent. For instance, there is no clear methodology in terms of which phrases were chosen for each line. In each group of numbers, one of the Evangelists necessarily ends up being privileged over the others, seemingly on the basis of whichever brief phrase within the group of texts being compared made the point best. While this approach is logical, it makes the quotations unsystematic. The numbers within these odd canons also do not match those in the following 'regular' canon tables perfectly. Often the lack of agreement between the two sets is simply due to the numbers being in a different order, but at times they are just wrong, or are missing altogether. ${ }^{25}$ For instance, in the concordance between Luke and John in canon IX, the regular canons list all of the various comparisons (fol. 24r), however in the initia canons there are six fewer agreements between Luke and John (fol. 10r, Fig. 2). Since they were writing out phrases, skipping some that were perhaps redundant was a way of streamlining things to save space and time when writing these out. But they no longer coincide correctly with the other set of canons, and are therefore not as comprehensive and methodical as they theoretically should be. This fact reveals holes in how useful the initia canons would be if used in practice with the actual gospel text found later in the book.

24 For the Latin transmission of Eusebius, see Wordsworth/White 1911.

25 A good example of where the two canon tables don't match numerically is in canon III, where Matthew 112 and Luke 119 are being compared against various spots in John. The traditional number order for John, which is reflected in the regular canon tables in Poitiers 17 (fol. 21v) is: 87, 44, 61,8, 76, 90, 154, and 142. However, this is completely scrambled in the initia canons, which put John's numbers in this order: 90, 44, 61, 76, 87, 142, 8, 154. 
Curiously, the specific pieces of text that were chosen to be included at times result in a coherent thought, as if the text phrases were intended to be read together. ${ }^{26}$ It is possible that there was some expectation that these would be read through by the book's user, perhaps providing something of a 'cheat sheet' for the priest trying to remember where various ideas were discussed. Although it is certainly possible that these initia canons could have provided a helpful shorthand to the gospels for someone taking the time to go through them, Nordenfalk has pointed out that the type found here was too extensive to have been an effective liturgical tool. In his article 'Canon Tables on Papyrus', he discusses a sixth-century papyrus gospel book written in Greek and found in Egypt. This fragmentary manuscript has notes referring to various readings alongside some of the numbers in the canon tables, and he suggests they served as a table of contents for pericopes to be read during divine services. ${ }^{27}$ He points out, however, that these were devised differently than those found in Brescia, and therefore also Poitiers, which he asserts would never have been used liturgically in that way. ${ }^{28}$ This lack of functionality seems borne out by the further issue that the phrases quoted in the Poitiers initia canons are based on the earlier Vetus Latina version of the gospels, and therefore have many variants with the Vulgate text within the manuscript itself.

Yet they occupy a large amount of space-there are nearly 650 excerpts of text here, and they are written over thirteen folios, or twenty-five pages, and take up nearly two full gatherings. What is more, they have been carefully corrected, with several missed lines and words squeezed in after completion. ${ }^{29} \mathrm{All}$ of this would have required quite a bit of extra work by the scribe, and additional parchment, so the investment in time and money was considerable for what was ultimately a redundant text given the regular, and more comprehensive, set of numerical canons directly following them in the manuscript. Why, then, were they so important that it was worth the resources and effort to include them?

26 For instance, in canon VIII on fol. 10r (see Fig. 2), where Luke and Mark are compared, the snippets chosen for Luke 23, 25, and 27 compared against Mark 12, 14, 28, and 16 (respectively) read: 'Descendit capharnaum ibique docebat eos', 'erat in synagoga homo daemonium habens', 'Sed et spiritus inmundi clamabant tu es filius dei', and 'et non sinebat ea loqui quia sciebant eum'. In translation they read approximately: 'He went down into Capharnaum and there he taught them. In the synagogue there was a man who had an unclean devil. But the unclean spirits cried, saying: Thou art the Son of God. And he suffered them not to speak, because they knew him'.

27 Nordenfalk 1982, 37.

28 Nordenfalk 1982, 37.

29 See for example fols $7 \mathrm{r}$ and $11 \mathrm{v}$.
While it is certainly possible they were seen as useful, there may be another reason for their inclusion. I would suggest there is a focused effort in this manuscript to establish a lineage; a heritage for all that comes after. ${ }^{30}$ Beginning with the early version of Eusebius and moving through the initia canons, the reader is then presented with the Novum Opus letter by Jerome, ${ }^{31}$ the text of which is a common version typical of the eighth and ninth centuries (fols $15 \mathrm{v}-17 \mathrm{r}$, Fig. 3). ${ }^{32}$ It is as if we are moving forward in time: Jerome's work builds on that of Eusebius, and he explains how to use what he clearly discusses as a chart of numbers, which comprise the regular canon tables that follow. Here at last, on fol. 15v, we get the first real decoration in the manuscript: a simple three-line foliate initial B for Beatissimo with a small gold cross inscribed within the upper bowl. It is unusual that although the Novum Opus letter by Jerome has been included, his other letter traditionally included among gospel prefaces, Plures fuisse, has not. ${ }^{33}$ The unbroken quire structure reveals that nothing is missing within the book's text, so we can assume this letter was never included. ${ }^{34}$ This omission is a bit surprising, as the Plures fuisse letter discusses the Evangelist symbols and their connections to the Evangelists which, given the image, would seem to have been an appropriate text to include. However, there seems to be a rhythm to the prefatory texts: Eusebius on the canons, then the initia canons, followed by Jerome on the canons, and the numerical canons. As will soon be addressed, the Evangelist symbols receive their own discussion, so perhaps Jerome's Plures fuisse letter was simply unnecessary, and even a disruption, in the pattern of the texts that were chosen.

The regular canon tables are spread out over 17 pages, an unusual number that exceeds the more common pattern of twelve or sixteen. They are also not contained within a single quire as was typical, but rather begin in

30 McGurk 1962, 18-34, and esp. 25, sees two different sets of prefatory materials here, but I argue they were really intended to be taken together as a whole.

31 Jerome 1975, 1115-1116.

32 The text does not appear to have anything unusual about it. I have compared the text in Poitiers 17 directly to that in the earlier Echternach Gospels, Paris, Bibliothèque nationale de France, Lat. 9389, fols $1 \mathrm{r}-2 \mathrm{v}$, from the late $7^{\text {th }}$ or early $8^{\text {th }}$ century, the roughly contemporary Essen Gospels, Essen, Münsterschatz, MS 1, fols 14r-16r, as well as two later gospel books, Baltimore, Walters Art Museum, MS W.4, fols 20r-21v, and St Gall, Stiftsbibliothek, Cod. Sang. 50, fols 7r-10v, both dating from the third quarter of the $9^{\text {th }}$ century, and they are all virtually identical.

33 Jerome 1969.

34 Unless, as stated above in note 13, it was included on the now missing first two folios of the manuscript. 


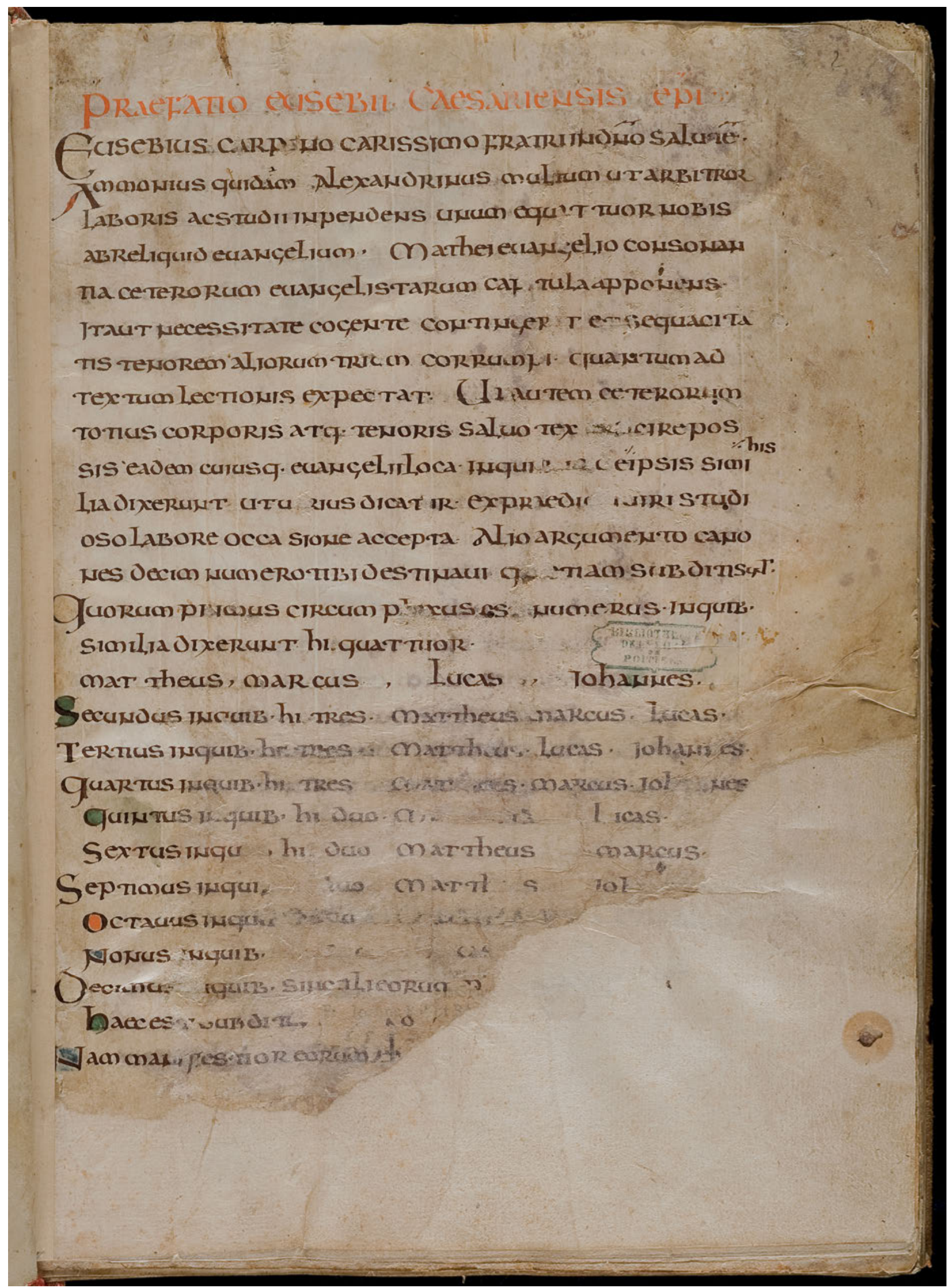

Fig. 3: Jerome's Novum Opus letter. Poitiers 17, fol. 15v. 


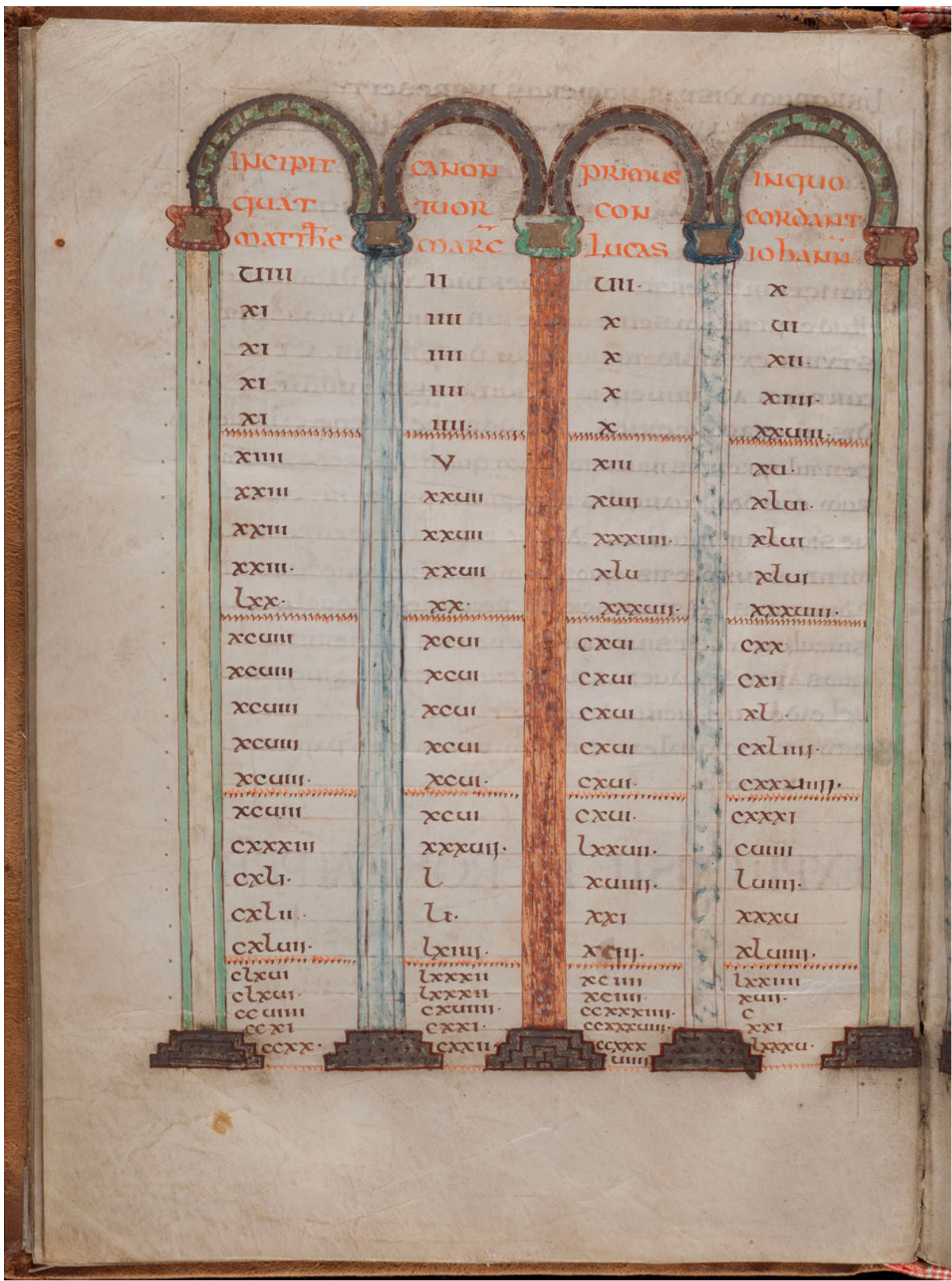

Fig. 4: Arcaded canon I. Poitiers 17, fol. 17v. 
one and end in another. ${ }^{35}$ As we come upon the columns and arches framing the first canon, painted in an array of colours including gold and silver (Fig. 4), they feel especially vivid due to the almost total lack of colour and ornament over the large amount of text pages up until this point. Having first processed through history, here at last we begin our procession through the arcade, bringing us closer, step by step, to God's truth.

The reader is met with attenuated columns and horseshoe-shaped arches, which lack a larger overall arch and therefore fall into Nordenfalk's classification of the ' $m$ ' type. ${ }^{36}$ Stylistically, they are not typical of Carolingian canon tables, which are more often of the ' $m$-n' type, creating the effect of a tympanum above the arcade. A handful of other Frankish canon tables, such as an early ninth-century gospel book from Augsburg now preserved in Brussels, and the somewhat later, so-called Gospels of Queen Theutberga, present the closest comparisons I have found to those in Poitiers 17, and show it to be perhaps on the early edge of a visual trend. ${ }^{37}$ In his study on the Gundohinus Gospels, Lawrence Nees suggested this form of column and arch is more eastern in style, and he saw them as suggestive of earlier Syriac manuscripts. ${ }^{38}$ Crosses in medallions over the arches found in Poitiers 17 connect with that tradition to some degree as well, as this motif shows up in Syriac canon tables such as in the sixth-century Rabbula Gospels. ${ }^{39}$ However, crosses in roundels are ubiquitous, so it is difficult to nail down this motif to a specific place or time. The cross motifs on the so-called 'Desk of St Radegunde', from the Abbey of Sainte-Croix in Poitiers where the manuscript came to be used, actually offer many similarities. ${ }^{40}$ Any direct stylistic relationship is unlikely, given the fact that the manuscript is not known to have been in Poitiers before the tenth century, but these roundels attest to similar motifs being used in the Frankish world from at least the sixth century. There is therefore a long visual history of crosses in roundels, in both east and west, and those in the Poitiers manuscript certainly carry the aura of those earlier traditions with them. However, parallels can be found in the Carolingian world as well, such as in a series of crosses that appear within the tympana of the canon tables in the early ninth

35 The canons start on fol. $17 \mathrm{v}$, the first folio of quire 3 , but end on fol. $25 \mathrm{v}$, the first folio of quire 4 .

36 Nordenfalk 1963, 20.

37 Brussels, Bib. des Bollandistes, MS 299, and the Gospels of Queen Theutberga, New York, Metropolitan Museum of Art, acc. no. 2015.560. 38 Nees 1987, 33-81.

39 Florence, Biblioteca Medicea Laurenziana, Plut. 1.56. 40 Musée Sainte-Croix, Poitiers, inv. \#B3954. century Harley Gospels. ${ }^{41}$ The ivory cover of the nearly contemporary Lorsch Gospels also contains a cross in a roundel, which is suspended by angels over an arcade in which Christ tramples evil underfoot. ${ }^{42}$ Therefore, while this motif certainly recalls earlier works, it was well integrated into Carolingian art by this time.

An unusual type of filler decoration within the tables, a penwork zig-zag and dot pattern used to separate the canons when they end midway through a page, does seem, however, to more distinctly echo earlier traditions (Fig. 5). The closest parallel I have found to this design is in the cross page of the Codex Usserianus Primus, which has been dated to between the fifth and early seventh century, and thoughts on its origins range from Ireland to the continent..$^{43}$ Despite the uncertainty today about its origins, there is no question that this gospel book represents a very early tradition of the Vetus Latina text. Nordenfalk believed this kind of penwork, where the design was created without lifting the hand from the page, was used by 'scribes of old' in colophon decoration, and he equated the technique and appearance to early scribal traditions. ${ }^{44}$ Perhaps the artist of Poitiers 17 was aware of the use of this type of motif within early gospels, and consciously quoted it for that reason. As demonstrated above, this would be well in keeping with the references to earlier gospel book traditions asserted so boldly through the opening texts of the manuscript. This stylistic choice, along with that of the eastern-style arches and the historically charged crosses in roundels, helps to visually build on the antiquity of the texts that came before, evoking the sense of a return to the foundations of Christianity.

Although this aggregation of elements from different sources is intriguing, it is not what is most remarkable about the canon table ornament in Poitiers 17. Rather, it is the way in which they unfold visually as one moves through them that is striking. Their effect is cumulative, building as they go much like the texts that precede them, and I have thus far found no comparison for this kind of progressive illumination in canon tables. In the first canon, where all four Evangelists agree, the columns and

41 London, British Library, Harley MS 2788.

42 Vatican City, Biblioteca Apostolica Vaticana.

43 Codex Usserianus Primus, Dublin, Trinity College Library, MS 55. The Codex Usserianus has been included in major studies, such as Lowe 1935, no. 271, but while all seem to agree on an early date for it, its exact dating and place of origin are still up for debate. A thorough study, and argument for seventh-century Ireland, has been offered in Ó Néill 1998, 1-28. A more controversial argument for a continental origin and earlier, fifth-century date, has also been put forward in Dumville 1999, 38-39.

44 Nordenfalk 1977, 13. 


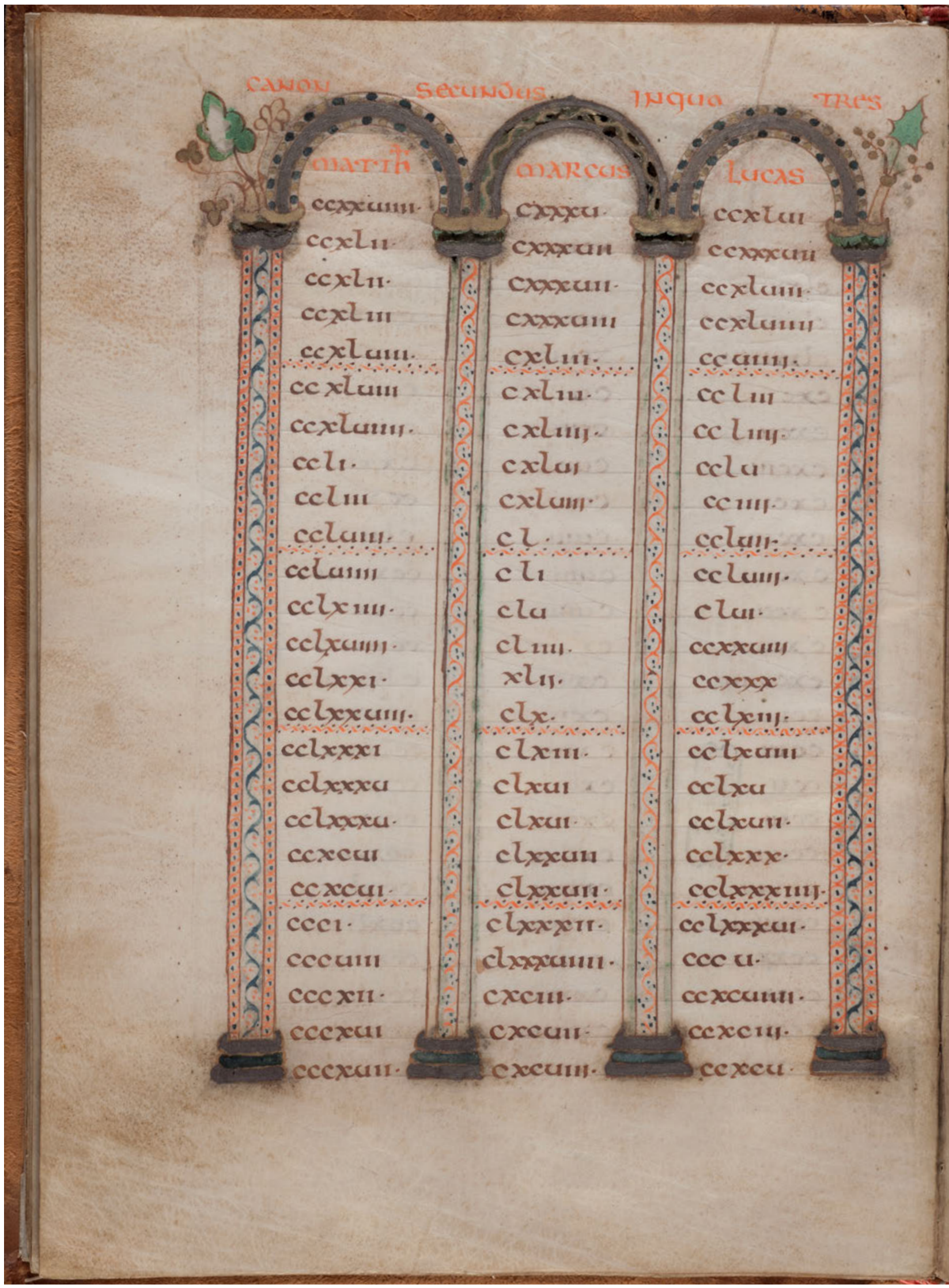

Fig, 5: Arcaded canon II. Poitiers 17, fol. 20v. 


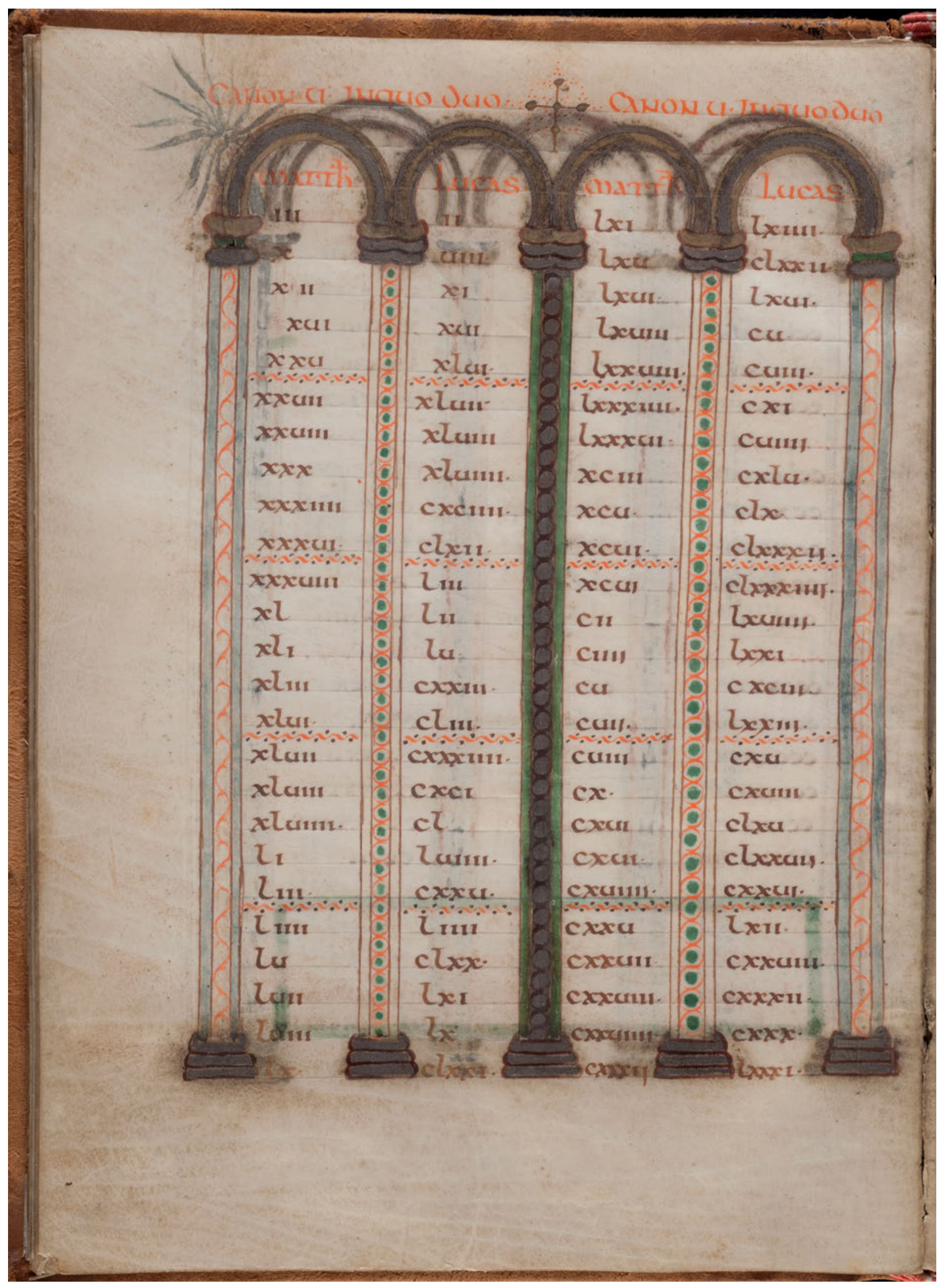




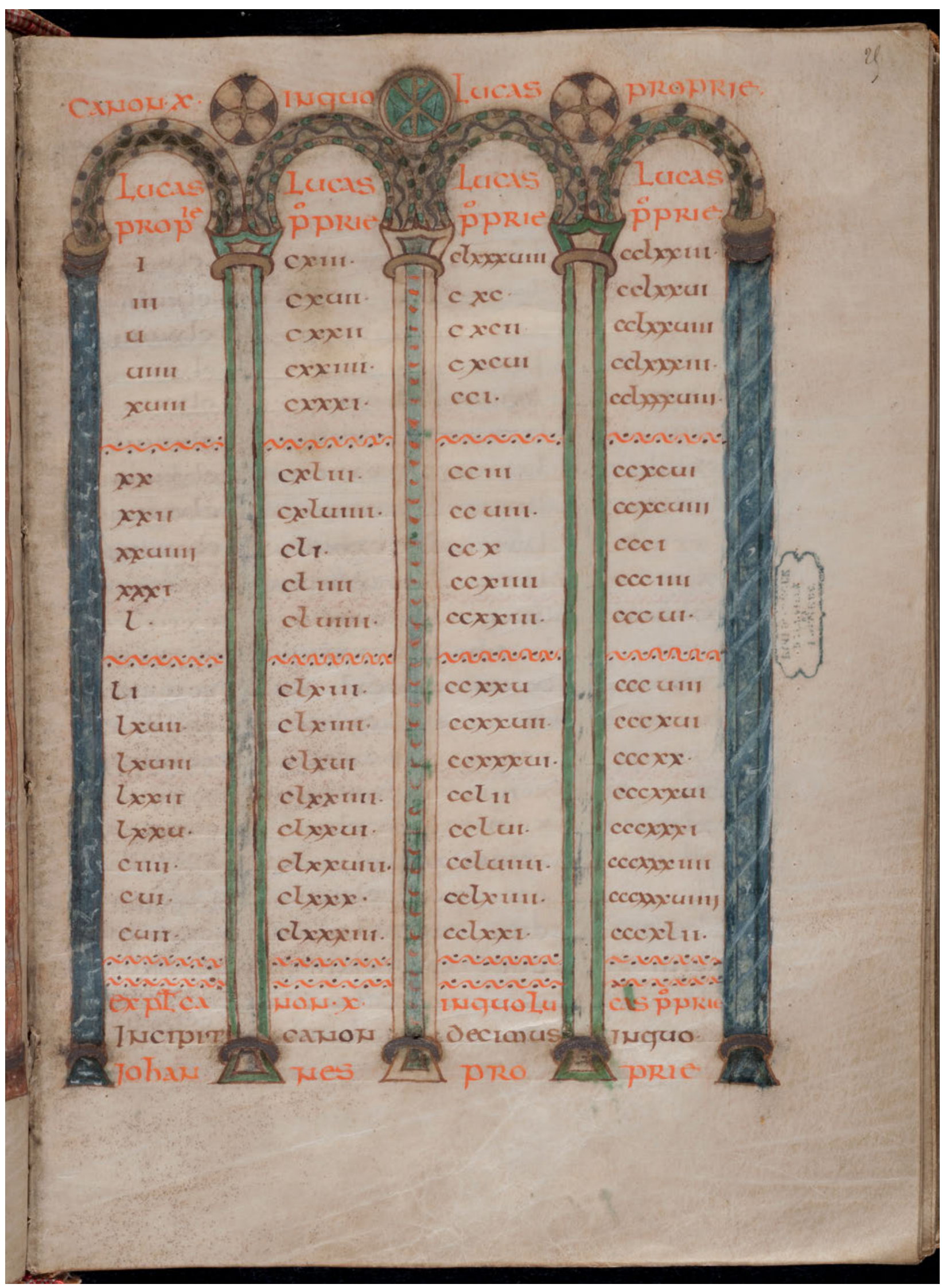




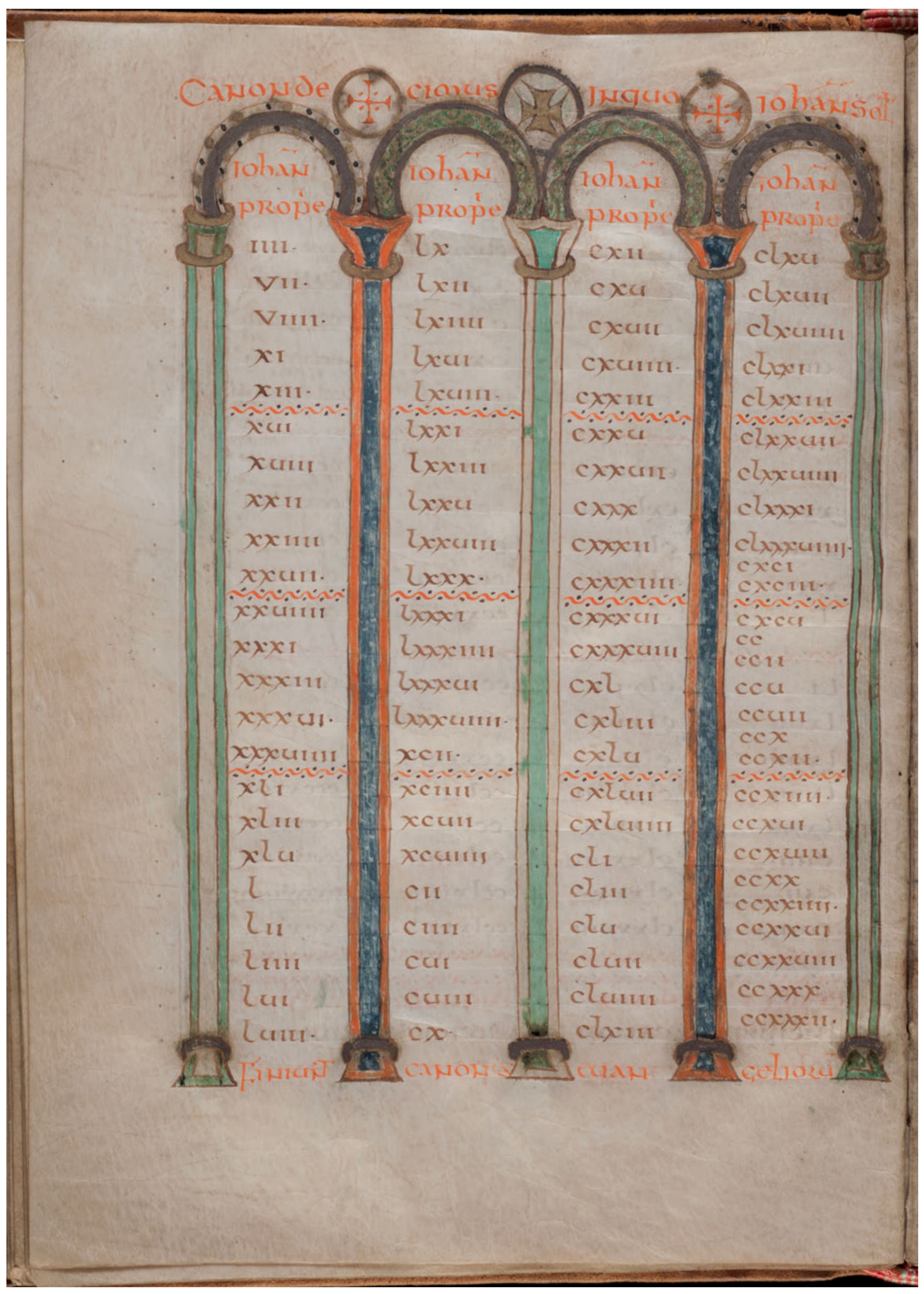

Fig. 8: Arcaded canon X. Poitiers 17, fol. 25v. 


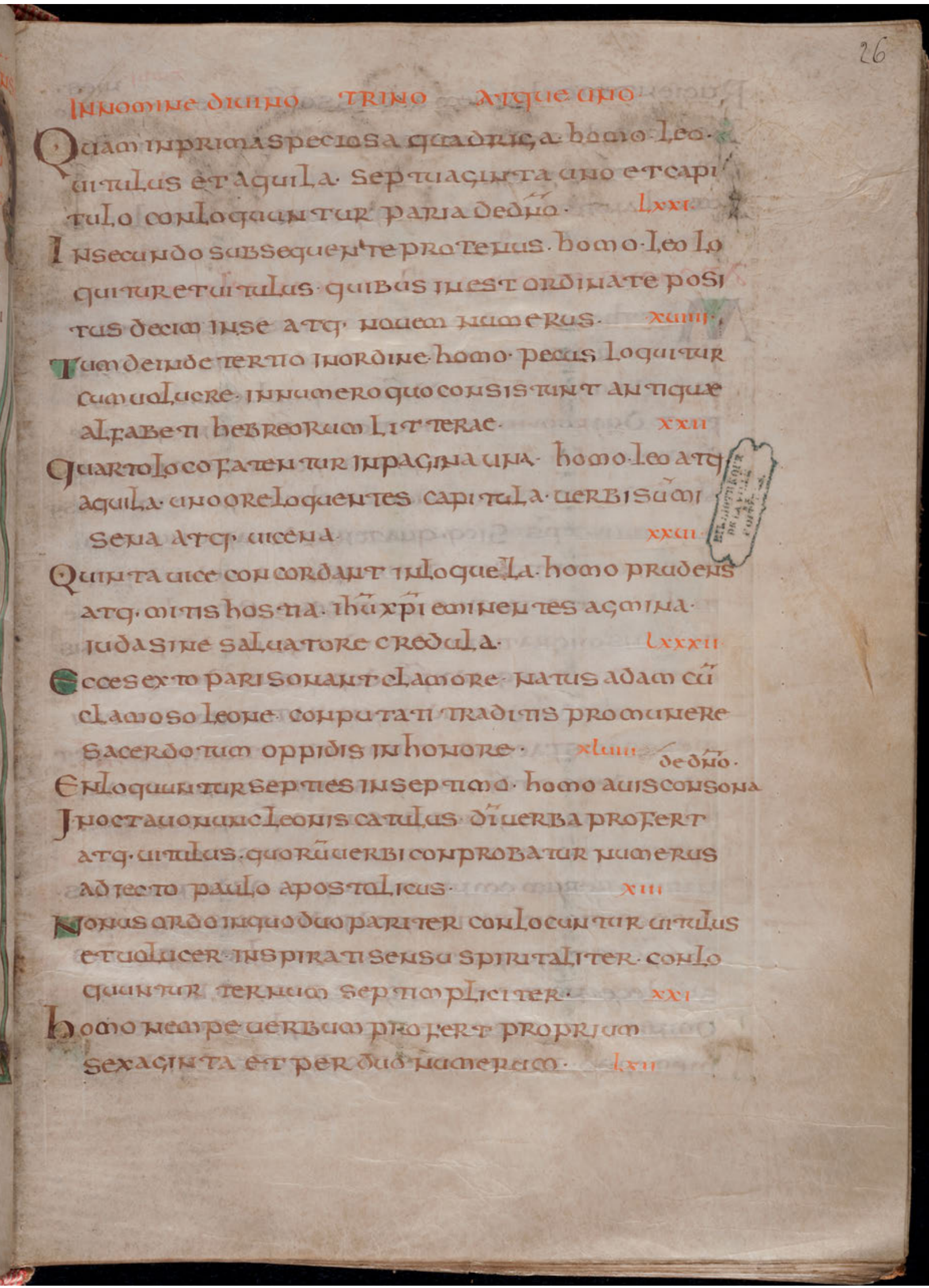

Fig. 9: Aileran poem. Poitiers 17, fol. 26r. 
arches have variety to their ornament, but have no decoration outside of their architecture (fols $17 \mathrm{v}-18 \mathrm{v}$, see Fig. 4). This plainer style proceeds into the beginning of the second canon (fol. 19r-v), then the arches begin to sprout vegetation as you move through canons II, III and IV, with fanciful palm fronds and holly leaves growing from the corners (fols 20r-22r, see Fig. 5). At the beginning of canon $\mathrm{V}$, where only two Evangelists agree, the foliate decoration gives way to single crosses over the center of the arches, starting with what appears to be a processional cross composed of gold orbs and red dots (fol. 22v, Fig. 6). Single crosses in roundels continue throughout canons $\mathrm{V}$ through IX, with most of the others being some variation of a Maltese cross in gold and silver (fols 23r-24r). ${ }^{45}$ Finally, as the Evangelists speak their own minds in canon $\mathrm{X}$ with readings unique to each, the lone cross in the middle becomes a golden Chi-Rho against a rich turquoise ground, and it is joined by two flanking crosses (fols $24 \mathrm{v}-25 \mathrm{r}$, Fig. 7). This is true of the tables with Matthew, Mark, and Luke, however John is treated differently. John's table receives a gold Maltese cross inscribed in a silver ring against a plain ground, with red crosses enclosed in gold rings on either side (fol. 25v, Fig. 8). This middle cross is notably larger than all of the others that came before, and is actually slightly tucked behind the top of the arches. While the odd change in the size and format of this last cross seems awkward, it is as if it has been given extra weight, and its difference is striking after the standardsized crosses that led up to it. All of this has further impact when taken with the facing page (fol. 26r, Fig. 9). Directly opposite these crosses is an unusual inscription, one that does not belong to the text written below it. ${ }^{46}$ It reads $I n$ nomine divino trino atque uno. This trinitarian phrase is rare, and I have only found it in a few other places, most notably in the colophon of the so-called Angilberga Psalter, dated $827 .{ }^{47}$ In the Poitiers manuscript, this carefully placed phrase about the Trinity aligns strikingly with the series of three crosses on the facing page, and in fact

45 The only other Carolingian canon tables I am aware of that have a series of crosses over the canons are in the Harley Gospels (London, British Library, Harley MS 2788), although they are not in roundels. 46 Howlett 1996, 14.

47 Piacenza, Biblioteca Comunale Passerini-Landi, Fondo Comunale, s.n. The colophon reads 'In nomine Divino Trino atque Uno incipit Psalterium Daviticum centum quinquaginta Psalmorum a viro Beatissimo Hieronymo Presbitero correctum atque emendatum distinctum versibus atque sententiis obelis et asteriscis scriptumque a nobis sub anno octingentesimo vigesimo septimo Incarnationis Domini Nostri Jesu Christi Amen'. See Brunati 1838, 93. Alcuin also uses a similar phrase: 'In nomine divino trino incipit sententia prima de operibus sex dierum cum puerorum interrogationibus et responsionibus ejus'. See Alcuin 1851, col. 1099. the word trino, which has been separated somewhat from the words around it and centered on the page, is almost literally circled by the ghosting of the silver ring from the central cross it faces. It is hard to imagine that this Trinitarian iconography and text were not intended to be read together across the page.

The text below this inscription is a seventh-century poem about gospel harmony by the Irish writer Aileran. While it is an unusual and unexpected addition, ${ }^{48}$ this poem is highly appropriate following the regular canon tables. It explains the agreement of the Evangelists within the canons in terms of a conversation being held between the beasts that represent them, and it is filled with number symbolism based on the divinely perfect number of agreements within each canon. ${ }^{49}$ Although the text makes its point eloquently and provides a fitting reflection on the abundance of canon tables that precede it, close inspection reveals that the 'perfect' numbers discussed within the poem do not always match both those in the regular and in the initia canons within the Poitiers manuscript. In fact, neither set matches Aileran exactly, so it appears to be more of an idea rather than something the manuscript's creator was set on proving. ${ }^{50}$

This poem does important work within the overall programme, however, for it ties together the canon tables that led up to this point with the image that follows, and in fact sets the stage for the Evangelists, who are represented in their zoo-anthropomorphic forms. Aileran's poem begins:

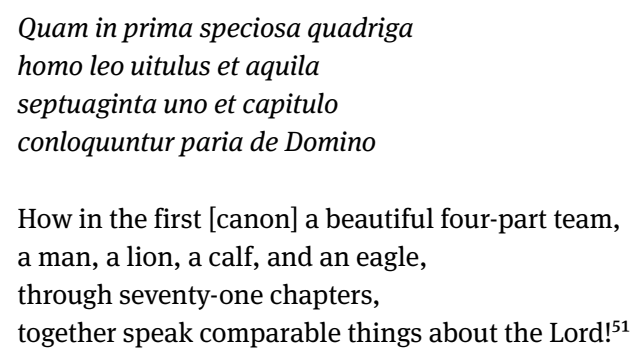

48 It survives in thirteen total manuscripts from the early eighth to the eleventh century, and they are Insular, Carolingian, and Italian. See full discussion in Howlett 1996, 11-20, and Netzer 1994, 61, 82, 119, and 205-206.

49 For a translation as well as explanation of the number symbolism, see Howlett 1996, 11-20.

50 Initia canons I, V, IX, and John's part of X do not match the Aileran poem; John's part of X in the regular arched canons also does not match Aileran, although the two sets of canons tables agree with each other on this particular part.

51 Here I have transcribed the text as written in Poitiers 17, which shows some variants with other versions in the second two lines. For how it varies from other versions of the text in Latin, as well as the English translation, see Howlett 1996, 12-16. 


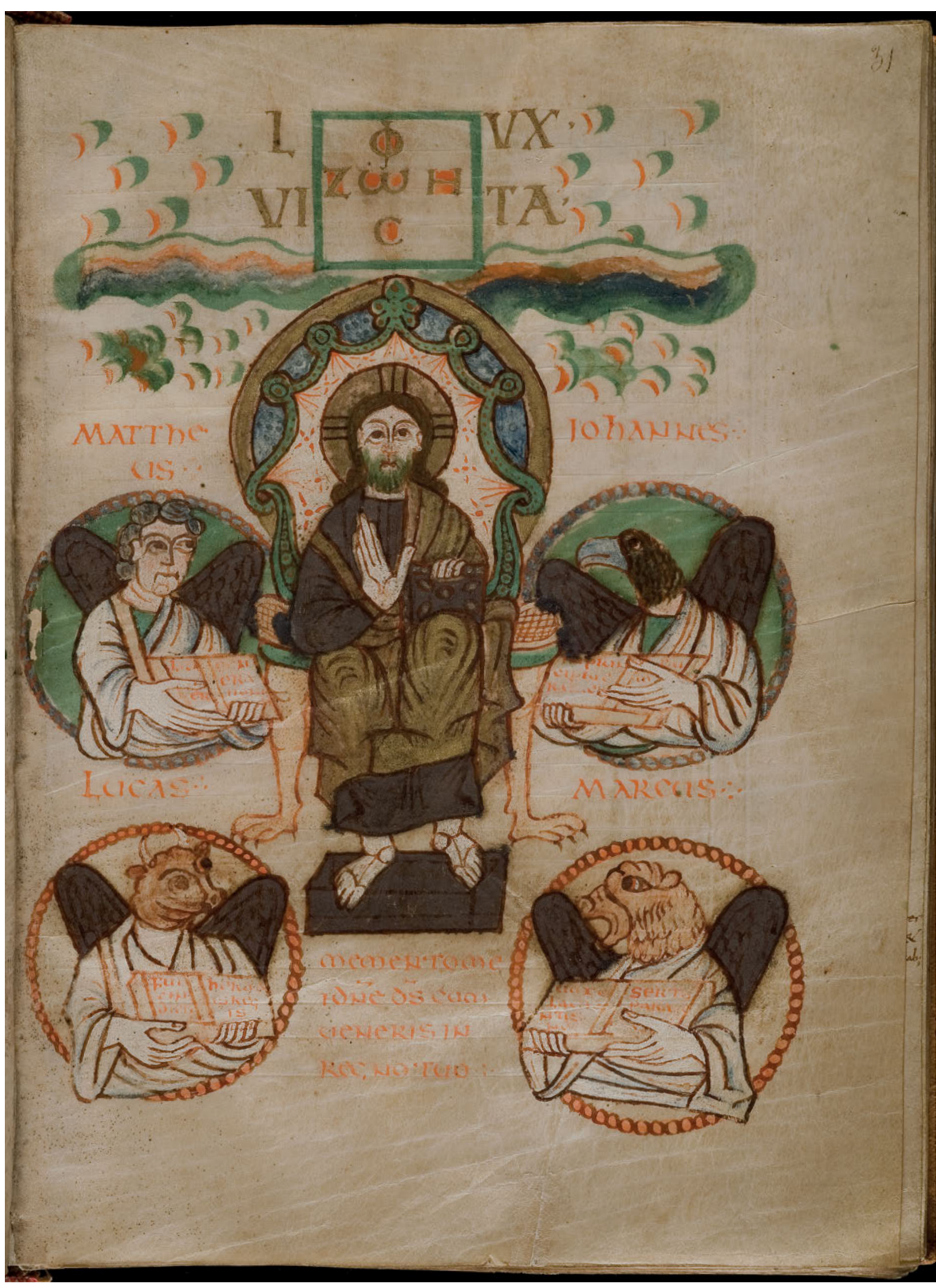

Fig. 10: Maiestas Domini. Poitiers 17, fol. 31r. 
The language used in the poem gives the creatures human qualities as they 'speak', 'clamour', and 'utter'. ${ }^{52}$ Thus, when one reaches the image a few folios later, it is perhaps not so surprising to find that the beasts are half human, and gesture to the text of their gospels as if discussing it, with Christ serving as the focal point of their conversation. The image, in many ways, serves as a visualization of the poem, just as the poem gives literary form to the charts of numbers that came before it.

After Aileran's poem comes Matthew's Argumentum, chapter list, and Hebrew names (fols 26v-30r). Turning the page at the end of these texts unveils the culmination of all of the prefatory materials, and the introduction to the actual gospels themselves: the image of Christ enthroned with Evangelist symbols (fol. 31r, Fig. 10). The image, the only one in the manuscript, is isolated as its own element-it neither faces the end of Matthew's prefaces nor the opening of his gospel, but rather faces a blank page, and itself has a blank back. These are the only pages left blank within the entire manuscript, and this separation allows the image to apply to all that has come before, as well as what comes after. It also forces the reader to pause, to read and contemplate the inscriptions on the image, rather than taking it as just decoration for the opening words of the gospels. There are no separate Evangelist portraits to introduce the gospels, so this image must speak for them all.

As I have argued elsewhere, the image in Poitiers 17 is a complex and sophisticated tour de force of Carolingian visual exegesis. ${ }^{53}$ One of the more remarkable aspects of the miniature is its programme of duality, which builds on the rhythm of doubling found in the canons. Most prominently, the image takes the two aspects of Christ, his humanity and his deity, and fuses them into one, for while at first appearing to represent a straightforward Maiestas Domini, it is in fact a double image, simultaneously representing Christ enthroned in heaven and on the cross. The artist employed a rippling cloud above Christ that at first glance merely suggests a heavenly setting. However, an inscription below Christ's feet recalls the Good Thief's words at the Crucifixion, while a dual Latin and Greek inscription overhead, LUX VITA/Z $\omega \mathrm{H} \Phi \omega \mathrm{C}$ ('Light' and 'Life' in both languages) forms a titulus crucis. These devices guide the viewer to interpret the undulating cloud as the horizontal bar of the cross, and the image is thus transformed. Through pious contemplation, Christ's dual nature is revealed: He is inseparably human and divine.

52 Latin: conloquuntur, clamore, and fatentur. See English and Latin edited in Howlett 1996, 15-16.

53 Herbert 2012, esp. 25-67, and Herbert 2016, 143-168.
Christ's duality is reflected in the very throne He sits upon, for its lion-footed base is that of an earthly king, while the throne back is encased in a golden half-mandorla containing a heavenly blue.

The unusual zooanthropomorphic forms of the Evangelist symbols surrounding Christ, who bear both human bodies and animal heads, serve to reinforce the dualities found within Christ's portrayal. But they do much more. Their presence is not passive; they do not simply inhabit the four corners as they often do in Maiestas images, but instead gather closely around Christ. The artist has cleverly brought these creatures into our own space, for they are not contained within their roundels, but rather emerge from them, their tunics, books, and wings breaking the plane of their inscribed pearl borders. Matthew's book in fact juts in front of the leg of the throne, even while his roundel passes behind it, giving the sense that he is reaching out toward the viewer. The effect suggests they are meant to be gathered around Christ's throne, rather than understanding Luke and Mark as relegated to a lower plane under Christ's feet. Christ gestures in speech, and as the Evangelists offer Him their books, they also hold them out toward us. By coming into our space, they are including us in the conversation. In holding out their books, they invite the reader to study their texts, they offer their secrets, they reveal the way to salvation. Their books make up the very book we hold, and that book is the key to enlightenment. By putting the Evangelists all together in this one image, rather than the far more common approach of having each one separately introducing his own gospel account, the emphasis has been shifted away from their individual contributions, and instead toward their harmonization. And by blending the human writer with his animal symbol, the image pushes us to think beyond the earthly authors and toward their more cosmic contributions. Gregory the Great, in his Homilies on Ezekiel, relates how each gospel writer's focus offered a key facet of Christ's story that, only when taken together, provide mankind with a complete understanding of Him. Gregory explains that Christ became man at His birth, was the sacrificial ox at His death, rose like a lion at the resurrection, and ascended to the heights like an eagle. ${ }^{54}$ This is conveyed not only in the choice of how the Evangelists are depicted, but also in the order in which they are presented. By revealing their crucial roles in Christ's overall story, the image validates the efforts of man to discover the harmonization and the interrelationships between the Evangelists' texts.

54 Gregory the Great 1971, 48. 
The multiple iterations of canon tables, and the letters and poetry of earlier theologians who painstakingly attempted to make sense of it all, serve as a testament to man's journey to see God's word clearly. These texts and charts may have been useful, but I would argue they also provided something of a historiography for the book's user, laying out the process through which the divine perfection of the gospels was unveiled. I have argued elsewhere that this manuscript was created under the guidance of Abbot Adalhard of Corbie, cousin of Charlemagne and one of the key theologians at his court. ${ }^{55}$ And I have connected this manuscript to Jesse of Amiens, who was head deacon at the court before being elevated to bishop in $799 .{ }^{56} \mathrm{He}$ and Adalhard worked closely together, and both were key in guiding theological thought within the court, as well as in their own work as spiritual leaders. It was a moment of intense debate regarding how to think about Christ's role in mankind's salvation, and these two men were in the thick of it. Adoptionism, a Spanish 'heresy' that was interpreted at the court as suggesting Christ was only God's adopted son and not fully divine from the beginning, was a major concern, and the dual nature of Christ emphasized in the image seems to respond to that ${ }^{57}$ Related to that concern was the filioque controversy, in which Charlemagne and his church leaders insisted on the Nicene Creed including the idea that the Holy Spirit issued from both the Father and the Son, placing a necessary emphasis on Christ's equal role in the trinity. ${ }^{58}$ These concerns regarding Christ's inseparably divine nature, and the equality of the trinity, seem to permeate the imagery in Poitiers 17, and it was the perfect truth of the gospel writers that could combat heretical suggestions to the contrary. Taken together, the amalgamation of texts and illuminations in Poitiers 17 may have provided important study and teaching tools for thought leaders like Adalhard and Jesse at such a critical time. The early texts provided a firm foundation on which the elegant architecture of the canons was built, allowing the reader to process confidently toward the inner sanctum of God's truth.

55 Herbert 2012, 86-95.

56 Herbert 2012, 99-117.

57 For an excellent discussion of all sides of this controversy, and the perspectives of those involved, see Cavadini 1993.

58 On this controversy, see Siecienski 2010. Jesse and Adalhard were intensely involved in this debate, and are named as meeting with Pope Leo together in the document Ratio de symbolo fidei inter leonem iii papam et missos caroli imperatoris, in Willjung 1998, 287. See also Gemeinhardt 2002, 160.

\section{Abbreviations}

CCSL $=$ Corpus Christianorum, Series Latina

MGH = Monumenta Germaniae Historica

$\mathrm{PL}=$ Patrologiae cursus completus, Series Latina, Paris: J.P. Migne

\section{References}

Alcuin (1851), Disputatio Puerorum per Interrogationes et Responsiones [Incertus], PL Cl, 1097-1144C.

Bischoff, Bernhard (1994), Manuscripts and Libraries in the Age of Charlemagne, Cambridge: Cambridge University Press.

Brunati, Giuseppe (1838), Dissertazioni bibliche, Milan: Tip. Pogliani.

Cavadini, John C. (1993), The Last Christology of the West: Adoptionism in Spain and Gaul, 785-820, Philadelphia: University of Pennsylvania Press.

Crawford, Matthew R. (2016), 'The Diatessaron, Canonical or Noncanonical? Rereading the Dura Fragment', New Testament Studies, 62/2, 253-277.

De Bruyne, Donatien (1927), 'La préface du Diatessaron latin avant Victor de Capoue', Revue bénédictine, 39, 5-11.

Dumville, David N. (1999), A Palaeographer's review: the Insular System of Scripts in the Middle Ages I, Kansai: Kansai University Press.

Ganz, David (1990), Corbie in the Carolingian Renaissance, Sigmaringen: Thorbecke.

Gemeinhardt, Peter (2002), Die Filioque-Kontroverse zwischen Ost-und Westkirche im Frühmittelalter, Berlin, New York: W. de Gruyter.

Gregory the Great (1971), 'Homiliae in Hiezechihelem prophetam', in Marcus Adriaen (ed.), CCSL, 142, Turnhout: Brepols.

Herbert, Lynley Anne (2016), 'Le toucher de l'Evêque: tracer les actes de dévotion dans les Evangiles de Sainte-Croix de Poitiers', in Éric Palazzo (ed.), Les cinq sens au Moyen Âge, Paris: les Éditions du Cerf, 143-168.

Herbert, Lynley Anne (2012), 'Lux Vita': The Majesty and Humanity of Christ in the Gospels of Sainte-Croix of Poitiers, PhD thesis, University of Delaware.

Howlett, David (1996), 'Seven Studies in Seventh-Century Texts', Peritia, 10, 11-20.

Jerome (1975), 'Praefatio in Evangelio', in Bonafatius Fischer, J. Gribomont, H.F.D. Sparks, W. Thiele and R. Weber (eds), Biblia sacra iuxta Vulgatam versionem, Stuttgart: Württembergische Bibelanstalt.

Jerome (1969), 'Commentariorum in Matheum libri IV’, in David Hurst and Marcus Adriaen (eds), CCSL, 77, Turnhout: Brepols.

Lowe, Elias A., and Rutherford Aris (1934-1966), Codices Latini Antiquiores: A Palaeographical Guide to Latin Manuscripts Prior to the Ninth Century, 11 vols, Oxford: Clarendon Press.

McGurk, Patrick (1962), 'An Anglo-Saxon Bible Fragment of the Late Eighth Century. Royal I E. Vl', Journal of the Warburg and Courtauld Institutes, 25, 18-34.

McGurk, Patrick (1961), Latin Gospel Books from A.D. 400 to A.D. 800, Paris: Éditions ‘Érasme'. 
Minard, Pierre (1943), 'L'évangélaire oncial de l'abbaye de saint Croix de Poitiers. Ses pièces inédites et ses particularités', $L a$ Revue Mabillon, 1-22.

Minard, Pierre (1945-1946), 'Témoins inédits de la vieille version latine des évangiles. Les Canons à Initia des évangéliaires de Sainte-Croix de Poitiers et de la Trinité de Vendome', Revue bénédictine, 56, 58-92.

Nees, Lawrence (forthcoming, 2020), Frankish Manuscripts 7th-10th Centuries, Manuscripts Illuminated in France, London, Turnhout: Harvey Miller Ltd. and Brepols.

Nees, Lawrence (1987), The Gundohinus Gospels, Cambridge, Mass: Medieval Academy of America.

Netzer, Nancy (1994), Cultural Interplay in the Eighth Century: the Trier Gospels and the Making of a Scriptorium at Echternach, Cambridge: Cambridge University Press.

Nordenfalk, Carl (1982), 'Canon Tables on Papyrus', Dumbarton Oaks Papers, 36, 29-38.

Nordenfalk, Carl (1977), Celtic and Anglo-Saxon Painting: Book Illumination in the British Isles 600-800, New York: Braziller.

Nordenfalk, Carl (1938), Die spätantiken Kanontafeln. Kunstgeschichtliche Studien über die eusebianische Evangelien-Konkordanz in den vier ersten Jahrhunderten ihrer Geschichte, I: Textband; II: Tafelband, Die Bücherornamentik der Spätantike, 1, Göteborg: Oscar Isacsons Boktryckeri A.-B.

Nordenfalk, Carl (1963), 'The Apostolic Canon Tables', Gazette des Beaux-Arts, 62, 17-34

Oliver, Harold H. (1959), 'The Epistle of Eusebius to Carpianus: Textual Tradition and Translation', Novum Testamentum, 3/1-2, 138-145.

Ó Néill, Pádraig (1998), 'The earliest drypoint glosses in Codex Usserianus Primus', in Toby Barnard, Dáibhí Ó Cróinín and Katharine Simms (eds), 'A miracle of learning': studies in manuscripts and Irish learning. Essays in honour of William O’Sullivan, Aldershot: Ashgate, 1-28.

Palazzo, Eric (2006), 'Tradition antique et "modernité" dans les évangiles de Sainte-Croix de Poitiers (Poitiers, Médiathèque François-Mitterand, MS 17 (65))', Ikonotheka, 19, Artem quaeris olit terra. Studia professori Piotr Skubiszewski anno aetatis suae septuagesimi quinto oblata, 67-81.
'Ratio de symbolo fidei inter leonem iii papam et missos caroli imperatoris', in Harald Willjung (ed.), Das Konzil von Aachen 809, MGH, Conc. 2, Suppl., 2, Hannover: Hahn, 1998.

Schmid, Ulrich B. (2003), 'In Search of Tatian's Diatessaron in the West', Vigiliae Christianae, 57/2, 176-199.

Siecienski, A. Edward (2010), The Filioque: History of a Doctrinal Controversy, New York: Oxford University Press.

Wordsworth, John, and H. J. White (1911), Novum Testamentum Latine, Oxford: Clarendon Press.

\section{Manuscripts referenced}

Baltimore, Walters Art Museum, MS W.4

Bamberg, Staatsbibliothek, Patr. 86 (B.V.13)

Brescia, Biblioteca Civica Queriniana, s.n.

Brussels, Bibliothèque des Bollandistes, MS 299

Cambridge, Magdalene College, Pepysian 2981 (I)

Dublin, Trinity College Library, MS 58 (A.I.6), and MS 55

Essen, Münsterschatz, MS 1

Florence, Biblioteca Medicea Laurenziana, Plut. I. 56

Fulda, Landesbibliothek Bonifatianus, MS 1

Leiden, Bibliotheek der Rijksuniversiteit, Voss. Lat. F. 26

London, British Library, Harley MS 2788

New York, Metropolitan Museum of Art, acc. no. 2015.560

Paris, Bibliothèque Mazarine, MS I

Paris, Bibliothèque nationale de France, Lat. 17225, and Lat. 9389

Piacenza, Biblioteca Comunale Passerini-Landi, Fondo Comunale, s.n.

Poitiers, Médiathèque François Mitterrand, MS 17 (65), Réserve précieuse

St Gall, Stiftsbibliothek, Cod. Sang. 50

Trèves, Séminaire, MS 40

Trier, Stadtbibliothek, MS 22

Troyes, Bibliothèque municipale, MS 138

Vendôme, Bibliothèque municipale, MS 2 
